\title{
Modelos e práticas de santidade feminina no Novo Orbe serafico brasilico, do frade Antônio de Santa Maria Jaboatão
}

\author{
William de Souza Martins
}

No projeto de pesquisa em desenvolvimento a respeito dos modelos e práticas de santidade feminina na América Portuguesa, propôs-se como método de trabalho um exame comparativo de fontes impressas que testemunharam a atuação religiosa de mulheres nas capitanias de Pernambuco, da Bahia e do Rio de Janeiro. Começando a análise com a obra do cronista Domingos do Loreto Couto, religioso beneditino, alguns resultados parciais já foram alcançados e divulgados para a capitania pernambucana. ${ }^{1}$ Neste texto, pretende-se dar sequência ao plano traçado no projeto, isto é, iniciar o exame do Novo Orbe serafico brasilico, sem dúvida, a obra mais importante do frade Antônio de Santa Maria Jaboatão. Segundo Venâncio Willeke, o cronista franciscano nasceu em 1695 na capitania de Pernambuco, tendo entrado no noviciado da Ordem dos Frades Menores em 1716 e efetuado a profissão religiosa um ano depois. Estudou Teologia e Filosofia no Convento de São Francisco da Bahia e, após ocupar diversos cargos na Província de Santo Antônio, foi escolhido em 1755 pelo capítulo provincial como cronista. De acordo com o mesmo estudioso, em 1757, os originais da primeira parte do Orbe Serafico foram encaminhados aos superiores da província. Mais tarde, em 1761, foram dados à estampa em Lisboa sob o título de Orbe Serafico, Novo Brasilico. Jaboatão teria falecido em 1779, após publicar diversas obras oratórias e deixar inúmeros panegíricos ainda inéditos. Fragmentos do manuscrito do Novo Orbe serafico permaneceram inéditos até o século XIX, quando foram editados pelo IHGB. ${ }^{2}$ É essa última edição que serviu de base à análise que consta a seguir. ${ }^{3}$

O Novo Orbe serafico pode ser considerado uma crônica geral da Província franciscana de Santo Antônio do Brasil. Em muitos casos, o conteúdo da obra assume um claro tom panegírico, ao defender a anterioridade do trabalho apostólico dos franciscanos na América Portuguesa, em comparação com os religiosos de outras ordens. Em outras passagens, tal como a que testemunha a atividade da beata Maria da Rosa na capitania de Pernambuco no século XVI, a crítica historiográfica mais recente encontrou indícios de anacronismo, a respeito da afirmação do cronista sobre a existência de uma associação de terceiros franciscanos seculares naquele contexto. ${ }^{4}$ Não obstante, a crônica de Jaboatão permanece fonte insubstituível, não apenas quanto à atuação dos religiosos da província, como também dos leigos e das religiosas com as quais os frades menores mantinham vínculos. No que tange aos fiéis, podem ser mencionadas as informações referentes às associações de irmãos terceiros seculares, fundadas desde o início do século XVII na referida província. Em uma posição intermediária, situada entre os leigos e os religiosos de ambos os sexos que professavam solenemente a vida monástica, aparecem também descritos na obra as beatas e ermitães, que faziam votos simples de castidade e, quase sempre, vestiam o hábito inteiro ou descoberto de alguma ordem terceira. Por fim, há na crônica de Jaboatão detalhes significativos sobre as práticas de devoção das freiras do Convento de Nossa Senhora do Desterro do Salvador, que seguia a Regra de Santa Clara, pertencente assim à família franciscana.

Os fragmentos que dão indícios de práticas religiosas femininas encontram-se dispersos no extenso relato de Jaboatão. Tais características afastam essa crônica da obra de Domingos do Loreto Couto, que reservou uma parte inteira de sua narrativa aos registros das vidas de mulheres virtuosas. Assim, se Loreto Couto assume claramente a intenção de compor um painel das virtudes heroicas de mulheres que habitaram a capitania de Pernambuco, esse propósito não está presente no Novo Orbe serafico. Um aspecto adicional parece ainda distinguir as duas obras, quando se consideram as práticas religiosas femininas. Em virtude das funçóes de cronista, o que lhe facultava acesso privilegiado aos arquivos conventuais e a memórias deixadas por eclesiásticos, Jaboatão confessadamente compila e traslada diversos 
relatos presentes em sua crônica, estabelecendo assim uma distância entre as fontes que utilizou e a sua narrativa autoral. A diferença assinalada torna-se evidente na própria edição da obra, por meio de uso de tipos impressos mais diminutos para indicar alguns dos textos compilados. Mais adiante serão comentados outros procedimentos que Jaboatão empregou na narrativa, que denotam a preocupação de manifestar a autenticidade das fontes de que se valia. Nas Glórias do Brasil e desagravos de Pernambuco, de Loreto Couto, esse tipo de cautela está menos presente. Com relação aos testemunhos do século XVII, o religioso beneditino cita pontualmente alguns cronistas da Restauração pernambucana, como os frades Manuel Calado e Rafael de Jesus, assim como Brito Freire. Entretanto, funde tais relatos em um texto próprio, acrescentando material de testemunhas orais e de outras fontes raramente especificadas. Com relação às atividades religiosas das mulheres no século XVIII, parece apoiar-se em fontes orais ou no seu testemunho pessoal, como fica evidente na descrição das mulheres virtuosas de sua própria família. ${ }^{5}$ Em resumo, a base de informação com que contavam ambos os autores era fundamentalmente diversa.

A forma da narrativa evidenciada nas duas obras afeta profundamente o tratamento conferido pelos autores às práticas religiosas femininas. Como já foi sugerido em outro lugar, em Loreto Couto a narrativa está estruturada a partir de uma hierarquia de modelos de perfeição religiosa, disposta em escala descendente. Em Jaboatão, as memórias relativas à atuação espiritual das mulheres encontram-se mescladas com outras informações da província franciscana de Santo Antônio. Nesse sentido, pode-se dizer que o plano de organização do Novo Orbe serafico, ao priorizar a disposição da matéria de acordo com as diferentes localidades e fundações conventuais relatadas, contribuiu para a dispersão das memórias relativas às mulheres. Enquanto isso, a narrativa de Loreto Couto incorpora claramente uma preocupação com o gênero, ao agrupar os relatos femininos em uma parte específica da obra.

Em Jaboatão, as narrativas acerca das mulheres surgem como apêndices de relatos mais vastos, que tratavam de matérias muito variadas. Mas nem todas as passagens que davam testemunho da atuação de mulheres serão alvo de análise. Neste trabalho, foi deixado de lado o fragmento que trata da beata Maria da Rosa, por ter sido várias vezes explorado pela historiografia. Por motivo diverso, também não foi analisada a narrativa da "vida e morte e boa fama" da sóror Vitória da Encarnação, religiosa professa no Convento de Santa Clara do Desterro da Bahia. Nesse caso, Jaboatão transcreveu, palavra por palavra, o livro raríssimo que o arcebispo da Bahia, D. Sebastião Monteiro da Vide, dedicara àquela religiosa, e que publicara em Roma em 1720. Por fim, foram também deixados de lado fragmentos secundários que informavam sobre a vida religiosa de mulheres de diferentes condiçôes, leigas ou religiosas, cuja pequena extensão não sustentaria uma abordagem mais detalhada. ${ }^{6}$

Assim, serão enfocadas aqui três passagens do Novo Orbe serafico reputadas como mais significativas, e que abordam as práticas de devoção de mulheres que dispunham de condições de vida muito diversas. Em primeiro lugar, situa-se a narrativa, baseada em um relato anônimo - cuja suposta autoria será mais adiante discutida - acerca da viúva Antônia de Pádua de Góes. Em sequência, será discutido o fragmento que aborda a vida virtuosa da beata Catharina Paes Landim. Neste caso, o cronista do Novo Orbe serafico publicou um manuscrito que the tinha sido entregue pelo prelado do Convento de Alagoas em 1762, "que trasladamos fielmente a sua narração; porque não queremos nesta parte dizer mais nem menos do que fomos informados". ${ }^{7}$ Por fim, será analisado o mais extenso relato, que dava conta da vida espiritual da sóror Maria da Soledade, religiosa professa no Convento de Santa Clara do Desterro da Bahia. Neste caso, a descrição de Jaboatão está fundamentada em uma memória produzida pela madre Margarida da Coluna, abadessa daquele Convento. O manuscrito, conservado pelo cônego da sé metropolitana João Borges de Barros, sobrinho da religiosa Margarida da Coluna, foi publicado por Jaboatão com as seguintes cautelas:

Nele não acrescentamos de mais que o reparti-lo em capítulos, e dessecando-o somente em algumas repetições menos necessárias, e nem foi possível o fazer isto em outras muitas partes dele, porque então seria forçoso mudarmos a escrita e total narração dela, e perderia a Autora o seu trabalho, e o zelo com que o fez para crédito seu, de suas Irmãs e da Religião de quem é filha. ${ }^{8}$ 
Pelo que ficou esboçado acima, apesar de extremamente impressionista, o relato de Jaboatão apresenta uma amostra da variedade da vida religiosa encontrada entre as mulheres coloniais. Vivendo dentro dos seus próprios lares na condição de simples fiéis, vinculadas às ordens terceiras como beatas ou ainda ocupando o espaço institucional da clausura, em que tinham prometido seguir os três votos característicos da vida religiosa, eis a diversidade que pode ser descortinada no Novo Orbe serafico. Como interpretar esses pequenos fragmentos da vida espiritual feminina na América Portuguesa? A historiografia, seja aquela diretamente dedicada à América Portuguesa, ou então os estudos voltados para os domínios de Castela e para a Europa no início do período moderno, vem apresentando algumas possibilidades de leitura, que podem ser aplicadas com adaptações à interpretação das passagens assinaladas do Novo Orbe serafico. Trabalhando especificamente com conventos e recolhimentos na região sudeste da América Portuguesa na segunda metade do século XVIII, a análise pioneira de Leila Algranti mostrou como o espaço da clausura funcionava simultaneamente como lugar de imposição de disciplina e de manifestação de autonomia para a condição feminina na Colônia. Nos estudos desta autora, torna-se perceptível a diversidade de aspirações presentes entre as mulheres que dividiam o espaço conventual: o desejo de seguir uma vida espiritual mais perfeita; o retiro forçado na clausura, por pressão dos familiares que as confinavam por não encontrarem pretendentes masculinos, com o mesmo status social, com os quais pudessem casar; educandas; mulheres internadas provisoriamente pelos maridos ausentes etc. ${ }^{9}$ Em um estudo focalizado nos estabelecimentos femininos de reclusão da capitania de Pernambuco, Suely Creusa Cordeiro de Queirós encontra um quadro análogo de diversidade entre as mulheres reclusas. Neste estudo, e em outros trabalhos da autora, parece mais inovadora a concepção do recolhimento como lugar de passagem, onde órfās podiam esperar com segurança o momento de contraírem o casamento; onde mulheres casadas ou solteiras eram encarceradas punitivamente para depois retornar ao século; ou ainda onde devotas esperavam transformar em conventos regulares aqueles estabelecimentos informais de reclusão em que se encontravam. ${ }^{10}$ Em estudo acerca do Convento de Santa Clara do Desterro da Bahia, Anna Amélia Nascimento interpreta a vida conventual feminina a partir do contexto socioeconômico e institucional da primeira capital da Colônia, tendo fundamentado a sua abordagem a partir da perspectiva da História Social. Já os trabalhos de Célia Maia Borges e Margareth de Almeida Gonçalves aproximam-se mais de uma História da Espiritualidade, pautada pela análise da incorporação dos modelos espirituais de uma religiosidade reformada (a devotio moderna, o ascetismo, o misticismo) à vida religiosa feminina, particularmente as beatas e freiras. ${ }^{11}$

Por fim, e sem ter a pretensão de um balanço exaustivo, caberia assinalar aqui a perspectiva assumida por Lígia Bellini, em estudos mais voltados para a península ibérica. Afastando-se de uma História da Espiritualidade em sentido estrito, a autora lança um olhar atento sobre as narrativas de devoção elaboradas por religiosas professas em Portugal. Nesses trabalhos, em que aplicou inclusive métodos quantitativos, pôde perceber que tais narrativas se estruturavam a partir da valorização de determinadas virtudes, o que confere a tais relatos características padronizadas de perfeição religiosa. ${ }^{12} \mathrm{~A}$ título de exemplo, parece muito profícua a perspectiva da autora em distinguir três momentos particulares em tais relatos de conversão: os primeiros anos da infância, em que surgem já anunciadas as excepcionais qualidades espirituais das mulheres devotas; o momento de conversão, assinalado por doenças e tensões familiares, em que as devotas, afastando-se do núcleo doméstico, reorganizavam a sua vida espiritual em outro patamar de devoção; e o momento da morte, que culminava com milagres e outros acontecimentos extraordinários, em um caminho espiritual caracterizado pela busca da perfeição. A esse respeito, pode-se acrescentar a percepção de Maria de Lurdes Correia Fernandes, quando esta aproxima o gênero literário dos escritos de vida à narrativa hagiográfica, em virtude da ênfase nos modelos de conduta religiosa. ${ }^{13}$ Parece útil também aplicar à análise das biografias e dos escritos de vida a abordagem que Certeau desenvolveu para a narrativa hagiográfica, segundo a qual "na hagiografia a individualidade conta menos que o personagem. Os mesmos traços ou os mesmos episódios passam de um nome próprio a outro". ${ }^{14}$ Em síntese, 
a partir das balizas historiográficas mencionadas, e de outras que serão referidas ao longo do trabalho, a leitura das práticas e dos modelos de santidade feminina presentes no Novo Orbe serafico será obtida a partir dos enfoques próprios da História Cultural, da História Social, da História das relações de gênero, bem como em uma análise comparada dos gêneros da literatura religiosa da época.

Focalizando em primeiro lugar o relato de Antônia de Pádua de Góes, Jaboatão informa que descendia pelo lado paterno de Gaspar de Araújo, natural da Vila de Arcos, e pelo lado materno de Catharina de Góes, nascida em Lisboa. ${ }^{15}$ A filha do casal também tinha nascido na capital do Reino, juntamente com outro irmão, denominado Simão. O casal se fixara com os dois filhos na capitania de São Jorge dos Ilhéus, por volta de 1563, onde tiveram mais quatro crianças: Francisca, Maria, Clara e Jorge. Após o falecimento da mulher, e já tendo "acomodado" toda a prole - o que significou, para os filhos homens, a conquista de algum tipo de ocupação e, para as mulheres, a passagem para o estado de casada - o patriarca Gaspar de Araújo pediu para ser admitido à Companhia de Jesus no Colégio da Bahia, tendo sido atendido pelos jesuítas. Esse ingresso foi também registrado na obra de Serafim Leite. ${ }^{16}$

Antônia de Pádua de Góes, a filha mais velha, foi também a primeira a contrair casamento. O cônjuge, Domingos da Fonseca Saraiva, era neto de Francisco da Fonseca Saraiva, o senhor da vila de Trancoso em Portugal. Estabelecido na vila de Ilhéus com "Engenho real de água, com grande número de Escravos Pretos e muitos Índios serviçais", o casal dera à luz dez filhos. Naquela localidade passaram cerca de vinte anos, após o que tiveram que se retirar, por força das "contínuas invasões do gentio", deixando para trás o rico patrimônio acumulado. ${ }^{17}$ Passaram então à localidade da terra firme do Cairu, também situada na comarca de Ilhéus, onde outros moradores foram se estabelecendo, "assim por casamento das filhas, como de outras Pessoas do Reino, que haviam passado à Bahia, a quem os Governadores foram fazendo datas e sesmarias de terras". Na referida localidade, os moradores levantaram a matriz de Nossa Senhora do Rosário do Cairu, cuja invocação passou a denominar também a Vila, que foi fundada em 1565. ${ }^{18}$ Além da matriz, os povoadores erigiram uma capela dedicada a Santo Antônio, que em 1649 foi doada aos frades franciscanos para que estes tivessem na vila um hospício ou pequeno estabelecimento conventual. Em 1654, Bento Salvador e sua mulher Isabel Gomes concederam por meio de escritura uma data de terra para estabelecimento de um recolhimento para os frades menores, cuja fundação utilizou o templo de Santo Antônio já existente. ${ }^{19}$ Em data incerta anterior a 1681, a referida fundação passou à categoria de convento. ${ }^{20}$

De certa maneira, a trajetória de Antônia parece seguir os passos do pai, pois depois da morte do cônjuge e do estabelecimento das filhas, pôde, segundo Jaboatão, se empregar "sem embaraços" ao serviço de Deus: "se deu dali em diante a todo o gênero de mortificaçóes, jejuns, cilícios e disciplinas, que eram as suas melhores iguarias." Essa passagem do relato de Antônia de Pádua de Góes é a única a fazer referências às práticas de ascetismo. Assim, devido ao caráter relativamente isolado que ocupa no conjunto da narrativa, parece constituir um eco das virtudes convencionalmente associadas às mulheres virtuosas nos relatos de devoção. Dentre todas as virtudes valorizadas pelo cronista franciscano, destaca-se sem dúvida a da caridade. Desde antes do casamento, Antônia parece ter se distinguido na prática da ajuda aos necessitados. A este respeito, o texto do cronista faz referência a um episódio que tem o sabor de um relato hagiográfico. Em uma ocasião, o marido achara demasiadamente alto o valor de uma esmola dada por Antônia, que se desculpou dizendo-lhe que não fora tanto quanto imaginara. Sentindo ainda a desconfiança do marido, ajoelhara-se diante do mesmo, e ordenara a uma serva da casa que colocasse sobre as palmas das mãos estendidas uma chapa de metal em brasa, dizendo "- Senhor F. assim como o que dizeis é verdade, assim abrase estas mãos este ardente ferro. E o teve nelas largo tempo". ${ }^{21}$ Ao presenciar tal cena, Domingos da Fonseca Saraiva prostrou-se também aos pés de Antônia, perdoando-a e ficando convencido da verdade do que ela lhe dissera. Nesse relato, percebe-se que Antônia aplicara a si mesma um castigo que teria merecido por atrair as desconfianças do marido. O lugar do corpo escolhido parece também significativo, isto é, as mãos que tinham feito o gesto de caridade. 
De fato, é provável que, nessa passagem, Jaboatão ou o informante em que se baseara tenham sido influenciados por narrativas de caráter hagiográfico. No âmbito da Ordem franciscana, pode ser citado o famoso milagre das rosas, associado à legenda de Santa Isabel, rainha de Portugal (1271-1336). O episódio foi relatado, entre inúmeros cronistas da Ordem dos frades menores, por frei Antonio Arbiol:

Levando um dia muita quantidade de dinheiro na extremidade ou fímbria de seu manto para reparti-lo entre os pobres, como acostumava, acertou de encontrar-se com o Rei seu marido, e perguntando-lhe que era o que levava, respondeu que levava rosas. Admirou-se o Rei, porque era tempo de Inverno; e olhando com atenção o que levava, achou que verdadeiramente eram rosas, verificando nosso Senhor com aquele patente milagre o que havia dito a santa. ${ }^{22}$

Tanto o escrito da vida de Antônia de Pádua de Góes como o relato das atividades atribuídas à Santa Isabel se constituem como relatos de mulheres casadas, cujo empenho nas práticas de caridade atraiu a desconfiança dos respectivos maridos. Enquanto no caso da primeira mulher o perdão do marido é consequência do severo castigo físico que Antônia inflige a si mesma, em relação à santa portuguesa as dúvidas são dissipadas por meio de um milagre. ${ }^{23}$ Nos dois relatos, é nítida a intenção dos cronistas e hagiógrafos no sentido da constituição de um modelo ideal de esposa.

No estado de viúva, e padecendo de grave doença que a imobilizava abaixo da cintura, Antônia de Pádua de Góes intensificou as práticas caritativas. Também a esse respeito, o paralelo com a legenda de Santa Isabel é próximo. ${ }^{24}$ Antônia atendia a enfermos pobres, "para os quais tinha em sua casa recolhimento separado", pedintes e a pessoas particulares. ${ }^{25}$ Sobre esse padrão caritativo, talvez caiba aqui sugerir que a própria enfermidade pode tê-la deixado mais sensível à caridade dirigida aos doentes. Assim, a viuvez e a enfermidade assinalam uma passagem importante na vida de Antônia, que se assemelha ao conflituoso momento da "conversão", presente quer nos relatos hagiográficos, quer nas narrativas de mulheres com reputação de santidade. A esse propósito, é interessante assinalar também o comentário de Lígia Bellini e Moreno Laborda Pacheco sobre a presença de enfermidades, naquele tipo de narrativa feminina. Nesse caso, suportar por anos a fio uma doença, como foi o caso de Antônia, pode também constituir um indício de virtudes. ${ }^{26}$ De forma análoga, Jacques Gélis analisou o lugar ocupado pelas doenças como etapa de aperfeiçoamento espiritual de homens e mulheres virtuosos. Os relatos valorizam ainda mais a reputação da santidade daqueles que sofriam em silêncio graves moléstias. Conclui o autor que "no combate permanente travado entre alma e corpo, tudo o que enfraquece o corpo só pode elevar a alma" ${ }^{27}$

Além das obras corporais de misericórdia, Antônia de Pádua de Góes destacou-se também no exercício das obras espirituais. ${ }^{28}$ Todos os dias de manhã, despendia meia hora de ensino da doutrina cristã para a sua família - que compreendia netos, escravos e netas - com vistas ao cumprimento das três virtudes teologais: Fé, Esperança e Caridade. Sobre o desempenho dessa atividade, Jaboatão relata que Antônia permanecia ainda mais tempo com as suas netas, "umas a cozer, outras a fiar", "postas em seus trabalhos e almofadas". Enquanto estavam assim ocupadas, a avó Antônia lia algumas partes do livro Jardim espiritual,

De sorte que fosse ouvida de todas, e lhes explicava algumas passagens, que disso necessitavam. O tempo, que destes espirituais empregos lhe sobrava, o ia ela divertindo tâo bem em cozer e remendar as camisas dos seus Netinhos, contando histórias das vidas dos Santos, da Paixão de Cristo e da Senhora, ensinando-lhes algumas Oraçôes particulares, das quais (diz o mesmo Autor, que era um daqueles seus Netos) me ensinou uma. ${ }^{29}$

Pelo que foi possível descobrir, o título completo da obra referida por Jaboatão era Jardim espiritual da doutrina dos santos varóes espirituais, publicada em 1632, na cidade de Lisboa, pelo frade franciscano Pedro de Santo Antônio. ${ }^{30}$ A passagem citada testemunha como as doutrinas e valores religiosos eram transmitidos no decurso das atividades cotidianas, em meio às quais as mulheres ocupavam posição de destaque. Por fim, encontra-se aqui um esclarecimento parcial a respeito da identidade do autor do manuscrito anônimo utilizado por Jaboatão. 
Além da caridade corporal e espiritual, o relato faz menção de dons terapêuticos acionados por Antônia de Pádua de Góes com a intervenção de imagens sagradas. Uma mulher levou à presença de Antônia um filho "quase moribundo, por causa da corrupção que tinha nas partes inferiores Secretas, e já lhe alcançava as Virilhas e barriga". Deitando a criança "naquele seu morto regaço", mandou que um dos netos fosse a uma igreja próxima e trouxesse um pouco de pó que caía de uma imagem carcomida de Nossa Senhora. Os restos de madeira foram então aplicados por Antônia nas feridas da criança, não sem antes invocar a graça da Virgem, dizendo "Senhora minha, curai este menino: porque não vá sua Mãe desconsolada”. Em poucos dias, informa o cronista, a criança teve a saúde restabelecida. Nessa passagem, percebe-se a combinação, no âmbito do culto à Virgem, de ideias defendidas pela Igreja - Nossa Senhora como mediadora preferencial do sagrado, acima dos demais santos - e de práticas de caráter popular toleradas pela instituição, como a atribuição de propriedades terapêuticas a resíduos materiais de uma imagem de Nossa Senhora.

Antônia de Pádua de Góes faleceu em 1643, aos 82 anos. Acompanhada dos frades franciscanos de quem era devota e protetora - da extensa família e dos últimos sacramentos, experimentou uma "boa morte", segundo os padróes devocionais da época. Mais uma vez, o relato se aproxima aqui do modelo presente na vida dos santos, em que uma morte considerada exemplar culmina uma vida coroada de virtudes. Foi sepultada na capela-mor da matriz de Nossa Senhora do Rosário de Cairu, acompanhada por "cento e dezesseis Filhos, Netos e Bisnetos seus, que juntos com os de seus dois Irmãos e quatro Irmãs podem hoje povoar um novo Mundo". 31

Tanto no relato de Jaboatão quanto no manuscrito anônimo em que dizia se basear, há motivos que levavam ambos os autores a exaltarem as virtudes de Antônia de Pádua de Góes. De fato, fora importante benfeitora dos religiosos franciscanos, além de figurar como ascendente do autor do manuscrito. Parece correto dizer que tanto o erudito cronista franciscano, membro da Academia Brasílica dos Renascidos, quanto o neto anônimo de Antônia - que não teve "outra Escola mais que a do A, B, C" foram influenciados pelos modelos narrativos das vidas de santos. ${ }^{32}$ No caso de Jaboatão, o uso deve ter sido consciente, na medida em que ele próprio elaborou narrativas com aspectos semelhantes, e que se encontram presentes em outras passagens do Novo Orbe serafico. Como letrado, certamente leu inúmeras obras com esse perfil, em diferentes momentos de sua formação e para finalidades variadas. No caso do autor do manuscrito, esse contato deve ter sido mais difuso e indireto, constituindo um importante começo as preleções sobre a vida de santos, da Virgem e da Paixão de Cristo que ouvira supostamente da avó ainda na infância. Nesse sentido, Antônia parece figurar na posição de um intermediário cultural, na medida em que adaptava à instrução religiosa dos iletrados (principalmente crianças e escravos) leituras extraídas dos manuais de devoção, cujas edições se multiplicaram no processo tridentino de reconquista espiritual dos fiéis. ${ }^{33}$ Ainda com relação à atividade de doutrinamento católico desempenhada pela biografada, pode-se aproximá-la do modelo de comportamento senhorial que importantes clérigos coloniais julgavam desejável no âmbito da elite proprietária de terras. ${ }^{34}$ Não obstante, o "pão espiritual" administrado por Antônia de Pádua de Góes não se destinava apenas aos escravos, mas também aos seus próprios netos, o que tornava a matriarca uma referência espiritual para os membros de sua extensa família. Assim, modelo de mulher casada e de viúva, Antônia de Pádua de Góes emerge do Novo Orbe serafico como espelho de perfeição para as mulheres da camada senhorial, promovendo a caridade material e espiritual para os colonos pobres, para seus filhos e escravos, e beneficiando os religiosos franciscanos com dotaçôes materiais.

A hipótese aqui proposta é que tanto Jaboatão quanto o neto de Antônia de Pádua de Góes, suposto autor do relato virtuoso, podem ter se inspirado em narrativas de vidas de santos, particularmente na de Santa Isabel. Além do fato de estar incluída entre os santos da Ordem franciscana, a canonização aprovada pela Santa Sé em 1625 pode ter contribuído para fortalecer muito o culto da santa, a julgar pela publicação imediata de narrativas acerca de sua vida. ${ }^{35} \mathrm{~A}$ santa franciscana também aparece com relativa 
importância na parenética da Restauração, marcada pela exaltação patriótica. ${ }^{36}$ Todas essas datas estavam cronologicamente próximas da morte de Antônia de Pádua de Góes, ocorrida em 1643.

O outro relato virtuoso escolhido para análise informa sobre a vida de Catharina Paes Landim, natural da Vila das Alagoas, filha de Manoel Landim e de sua mulher Catharina Paes. Segundo Jaboatão, o escrito de vida tinha sido fornecido pelo guardiáo do Convento de Alagoas, em 1762. O cronista franciscano, como já foi dito, publicou fielmente o manuscrito, que foi estampado no Novo Orbe serafico em caracteres tipográficos mais diminutos, o que permite diferenciá-lo do restante do texto do cronista. ${ }^{37} \mathrm{Na}$ medida em que o relato em questão dá continuidade às informaçôes relativas às fundações franciscanas na Vila de Alagoas, torna-se importante contextualizar a criação do convento dos frades menores. Segundo informa o próprio Jaboatão, fr. Cosme de São Damião havia se fixado naquela localidade em 1635, ao lado de outros religiosos que haviam saído de Pernambuco no contexto da guerra contra os holandeses. Tal como sucedeu na Vila de Cairu, os frades se estabeleceram em um recolhimento que possuía um oratório. Passada a ocasião dos conflitos, os franciscanos deixaram a Vila, fato que frustrou os moradores. Assim, em 1657, a Câmara e o Povo da Vila de Santa Maria Madalena da Alagoa do Sul e Norte enviaram uma petição ao prelado superior da Custódia de Santo Antônio, fr. Pantaleão Batista, solicitando "os restituir a sua posse antiga, e dar cumprimento à palavra dada de seu Antecessor de mandar levantar Mosteiro no lugar donde esteve, ou onde melhor lhe parecer para sua consolação". ${ }^{38}$ Nos anos seguintes, foram enviados religiosos e recursos para a construção de um novo recolhimento, onde uma primeira missa foi celebrada em 1662. Tais providências foram ainda consideradas insuficientes, de modo que em 1684 se lançou a primeira pedra do convento da Vila cuja construção foi concluída em 1723. Tal como costumam praticar em diversas províncias, os religiosos de São Francisco preocuparam-se em difundir a Ordem Terceira na Vila das Alagoas. Em 1719, foi nomeado o primeiro comissário dos irmãos terceiros da referida localidade, escolhido entre os frades da província para dirigir aqueles irmãos no plano espiritual. ${ }^{39}$

Cerca de um ano depois, em 15 de julho de 1720, Catharina Paes Landim tomou o hábito da Ordem Terceira de São Francisco na Vila das Alagoas. Cumprido o período de noviciado, professou na Ordem a 24 de agosto de 1721. Desde 1689 era casada com Antônio de Azevedo Castro, natural do arcebispado de Braga. $\mathrm{O}$ matrimônio não deu origem à prole. Não obstante, segundo informa o cronista, Catharina

teve uma Mulatinha, filha de uma sua Escrava, a quem criou com o recato de filha própria, e quando teve capacidade a forrou, e casou com um Pardo oficial de Alfaiate e Barbeiro, por nome Antônio dos Santos, que ainda hoje vive mui honrada e Cristãmente com a dita sua mulher, que se chama Margarida Rodrigues. ${ }^{40}$

Existe a possibilidade de que essa filha de criação tenha sido concebida por meio de contatos sexuais adulterinos de seu marido com a escrava. ${ }^{41}$ A crônica é vaga a esse respeito, fazendo apenas referências genéricas aos "desmanchos" e às "mundanas vaidades" de Antônio de Azevedo Castro. A tudo Catharina suportara com extrema paciência, "e tanto que só lhe estranhava as ofensas de Deus, e não a sua própria, sentindo mais a perdição de sua alma do que a da fazenda". A propósito, a irmã terceira revelou-se extremamente desapegada dos bens materiais, "despojando-se das roupas, que tinha mais lustrosas, e de preço, repartindo-as por algumas parentas pobres, ficando só com um manto de sarja e uma saia de baeta”. O vestuário exterior não revelava apenas simplicidade, mas também a busca da penitência. Esse aspecto transparece pelo interesse da devota em vestir o hábito descoberto da Ordem Terceira. Esse desejo repugnara de início o marido, embora depois Catharina tenha conseguido convencê-lo.

As práticas descritas por Jaboatão apontam para duas direções de certa forma complementares. Em primeiro lugar, aparecem uma vez mais ecos do relato hagiográfico de Santa Isabel. Arbiol menciona que a rainha de Portugal tolerara caridosamente as torpezas do marido D. Dinis, mandando trazer "a sua presença os filhos bastardos do Rei seu Esposo, e dava-os a criar com muito cuidado, providenciando sua boa educação e criação, e mandando-os prover de todo o necessário com muita largueza". ${ }^{42}$ 
Por outro lado, o relato de Catharina Paes Landim constitui mais um testemunho de variedades de vida espiritual que podem ser chamadas de intermediárias, na medida em que se situavam a meio caminho entre o mundo e o claustro. Existem vários detalhes na narrativa que permitem aproximar a devota alagoana ao modo de vida das beatas. Desde a Baixa Idade Média, no norte e no sul da Cristandade Ocidental, mulheres oriundas de diversos segmentos sociais abdicaram voluntariamente do matrimônio e das riquezas materiais, buscando viver na pobreza e guardar a castidade. ${ }^{43} \mathrm{O}$ desejo de levar uma vida religiosa mais perfeita, nos moldes do Evangelho, indica que esse movimento penitencial feminino estava inserido nas correntes de renovação da espiritualidade daquele contexto. ${ }^{44}$ Entre os séculos XIII e XV, tais mulheres foram incorporadas às ordens de São Domingos, São Francisco e do Carmo, entre outras congregações mendicantes. Por um lado, essa incorporação se deu por meio da imposição dos três votos solenes que caracterizavam o clero regular, bem como a observância da clausura, tendência que foi reforçada após o Concílio de Trento. Por outro lado, havia mulheres não integradas formalmente na vida monástica, e que prometiam manter simplesmente a castidade, vivendo em grupos ou isoladas. Chamadas de beguinas na Baixa Idade Média, no início do período moderno se tornaram mais conhecidas pela designação de beatas. ${ }^{45}$ Essas mulheres recebiam o hábito inteiro ou descoberto das ordens terceiras vinculadas aos frades mendicantes. As beatas utilizavam permanentemente esse vestuário, o que as diferenciava dos demais irmãos terceiros seculares, cujas vestes sagradas eram utilizadas apenas por ocasião das cerimônias de culto nas ordens. Para receber o hábito inteiro, a irmã terceira devia provar conduta moral irrepreensível, ter mais de quarenta anos, possuir autorização do marido ou do pai, e ter recursos que a poupasse de pedir esmolas pelos lugares públicos, "com descrédito do hábito". ${ }^{46}$ A resistência do marido de Catharina Paes Landim em autorizá-la a pedir o hábito descoberto da Ordem Terceira de São Francisco se explica porque a decisão levaria a mulher a guardar a castidade. Esse ponto é também evidenciado na análise de um historiador que estudou as atividades das beatas no México colonial:

Quase todas eram mulheres solitárias, solteiras (donzelas), viúvas ou separadas de seus maridos, ainda que houvesse várias que estavam casadas. Estas últimas insistiam, entretanto, que se haviam obrigado por um voto de castidade a não ter relaçôes sexuais com seus maridos, pois este era um requisito indispensável para a santidade. ${ }^{47}$

A busca do hábito descoberto pode ser considerada o ponto central no relato de Catharina Paes Landim, na medida em que indicava a passagem da terceira franciscana a um patamar superior de perfeição espiritual. Essa nova etapa foi assinalada pela mudança do próprio nome, conforme era o uso das mulheres que professavam solenemente nos conventos, "querendo ser tratada só por Catharina das Chagas". Além disso, "nunca mais usou calçado, e só trazia uns tamancos", sendo que na quaresma e em alguns dia do ano "andava totalmente descalça". Em uma ocasiāo, quando o marido ainda relutava em permitir que usasse o hábito, "ela lhe respondeu que ainda o havia ver feito ermitão; e assim o viu; porque houve tempo em que o mesmo marido se vestiu de ermitão, e neste estado morreu". Essa referência indica mais uma modalidade de vida religiosa presente nos tempos coloniais entre os homens leigos. Apesar da etimologia do nome, um estudioso mostrou que os eremitas não viviam isolados do contato com os demais fiéis. A responsabilidade da manutenção de um local de culto levava os ermitães a pedir esmolas nas moradias circunvizinhas. ${ }^{48}$ Assim, após viver em estado de pecado, o marido de Catharina teria mais tarde, em um momento não especificado na narrativa, se arrependido de seus erros e se convertido à vida eremítica. ${ }^{49}$

O relato descreve de modo mais ou menos convencional as práticas virtuosas que Catharina aprofundara após a tomada do hábito descoberto, tais como os jejuns, os flagelos e cilícios com os quais mortificava o corpo, as oraçōes, a posse de imagens piedosas e de "um painel bom do Senhor dos Passos, que mandou buscar à Bahia para armar um Passo no dia da Procissão que se faz na Vila”. Não obstante, a narrativa deixa em suspenso uma dúvida: após a conversão, teria se afastado totalmente do con- 
tato com o marido? Jaboatão informa apenas que "morava em uma Olaria, e nela trabalhava com umas negras e velhas, fazendo tijolos por suas mãos para ajuda de sustentar-se a si, e principalmente as mesmas Escravas". O seu local de habitação era de taipa coberta de palha, e no interior do mesmo mantinha um oratório com diversas imagens sagradas. Não se sabe se a referida moradia se localizava no interior da propriedade do casal. De qualquer forma, a prática de trabalho braçal ao lado de mulheres cativas indica também uma ruptura com a antiga condição senhorial. Assim, diferentemente de Antônia de Pádua de Góes, modelo de matriarca virtuosa, que dispensava instrução cristã, esmolas e dons curativos no interior da casa-grande, Catharina das Chagas exemplifica um modelo alternativo de virtude, em que mulheres coloniais abandonavam voluntariamente o vínculo matrimonial para viver em castidade e na pobreza. A narrativa se conclui com a morte piedosa da devota, em 1748.

A partir desse ponto, será analisado o terceiro e último relato do Novo Orbe serafico que, selecionado entre outras passagens que davam testemunho das práticas religiosas de mulheres, trata da "Vida e morte da Serva do Senhor Sóror Maria da Soledade" ${ }^{50}$ De acordo com o comentário inserido no início do trabalho, a narrativa fora elaborada por outra freira do Convento, Madre Margarida da Coluna, em cujo texto Jaboatão declarou ter suprimido apenas algumas repetições e acrescentado subdivisões. ${ }^{51}$ Antes de considerar propriamente o relato, é necessário situar as duas freiras mencionadas no âmbito do estabelecimento de reclusão onde passaram a maior parte de suas vidas: o Convento de Santa Clara do Desterro da Bahia. Fundado em 1677 por um grupo de religiosas da Ordem de Santa Clara proveniente de Évora, constituiu o primeiro estabelecimento religioso regular destinado a mulheres na Colônia. A Câmara e as outras autoridades locais foram as principais promotoras da fundação conventual, após superarem a relutância da Coroa. O perfil das famílias das primeiras freiras a efetuar os votos solenes indica uma origem social predominantemente de senhores de engenho e de grandes comerciantes, que compunham a elite socioeconômica colonial. $\mathrm{O}$ valor elevado dos dotes apresentados pelas religiosas no momento de ingresso, que entre os séculos XVII e XVIII oscilou entre 600\$000 e 2:000\$000 réis, constitui mais um indicador do perfil social seleto das que aspiravam ao noviciado. Assim, ao lado do fator devocional, não se pode ignorar que o Convento do Desterro tinha também um papel importante na regulação do mercado matrimonial do patriciado baiano, na medida em que garantia um destino honrado e seguro às filhas que não encontravam pretendentes masculinos do mesmo nível social para casar. Ao cabo, a referida prática tinha o efeito de manter o status das famílias locais mais proeminentes. ${ }^{52}$

Segundo o Novo Orbe serafico, Maria da Soledade nascera em 1668 na freguesia da Sé da Bahia, filha de João Borges de Macedo, natural da Vila de Cadaval, no Arcebispado de Lisboa, e de D. Maria de Barros, nascida na cidade do Salvador. Os pais eram "pessoas nobres" e bem conhecidas na localidade. $\mathrm{O}$ casal gerou nove filhos, dos quais apenas seis sobreviveram até a idade adulta. Na prole que restou, Maria da Soledade tornara-se a única filha. Desde a infância, segundo o cronista, "parecia ser a mais observante Religiosa, e tão bem inclinada que toda a sua ocupação foi logo cozer e fazer rendas para o concerto dos Altares". Tensões no âmbito familiar apareceram por ocasião da morte do pai, quando os irmãos quiseram casá-la "com um nobre cavaleiro vindo da Índia, chamado Christóvão de Souza Coutinho". ${ }^{53}$ A devota "resistiu grandemente" contra o projeto de seus parentes e, apoiando-se na mãe, tomou o estado de religiosa, entrando no Convento de Santa Clara do Desterro no dia 2 de fevereiro de 1687, festa da Purificação de Nossa Senhora. Após cumprir o período de noviciado, professou os votos solenes em 15 de fevereiro do ano seguinte. Em diferentes narrativas de vidas de santos, o caminho da vida religiosa quase sempre vinha acompanhado de obstáculos. No caso da santidade feminina, foram constantes os conflitos entre a preferência da família pelo matrimônio e o desejo das devotas de buscar um estado de perfeição espiritual, guardando a castidade. Para ficar com um exemplo significativo, pode-se referir o caso de Santa Clara de Assis, a fundadora da Ordem em que Maria da Soledade havia ingressado, que rompeu com os laços e projetos familiares para viver o ideal da pobreza evangélica. ${ }^{54}$ Assim, na terceira narrativa transcrita por Jaboatão, os relatos hagiográficos parecem também estar presentes como pano de fundo. No caso em questão, há outro ponto a considerar a esse respeito: a ideali- 
zação do período da infância das biografadas. Tanto no Novo Orbe serafico quanto nos relatos de Tomás Celano acerca da santa de Assis, a vocação e os exercícios da vida religiosa aparecem cedo na vida das biografadas, antecipando os rigores do claustro.

Assim, a hipótese a ser sustentada aqui é que madre Margarida da Coluna, a suposta autora da narrativa compilada por Jaboatão, inspirou-se nos escritos sobre a vida de Santa Clara para compor o seu próprio relato. Este foi elaborado em data incerta, situada entre 1719, data da morte de Maria da Soledade, e 1743, quando faleceu a biógrafa. É quase certo que Margarida da Coluna não se baseou diretamente em Celano, que compôs a primeira hagiografia de Santa Clara, mas em cronistas posteriores da Ordem de São Francisco, como Damian Cornejo, que também retratou a santa de Assis na infância como uma freira em miniatura. ${ }^{55}$ Após a profissão, Maria da Soledade restringiu ao máximo o seu contato com o mundo exterior, admitindo apenas falar com a mãe no parlatório conventual poucas vezes ao ano. D. Maria de Barros aparece descrita como "Santa Mulher e piedosa Matrona", o que revela mais uma coincidência desse relato com o de Celano, para quem o exemplo de Hortolana tinha sido decisivo para a vocação da filha Clara. ${ }^{56}$ Após o falecimento da mãe, Maria da Soledade não manteve comunicação com sobrinhos e irmãos, talvez ressentida com estes por terem pretendido casá-la a contragosto.

A prática devocional de Maria da Soledade continha muitos elementos para torná-la um exemplo de perfeita religiosa: extrema regularidade no exercício do coro, ao qual faltara apenas durante a prisão e nos três dias anteriores à sua morte; assistência frequente às missas; cuidado com os paramentos de culto; observância estrita do silêncio e da obediência; pobreza material; sensível devoção às representações de Cristo, seja no Santíssimo Sacramento do altar, no crucifixo ou na imagem do Deus Menino. Os cânticos e as orações vocais que tinham lugar no coro constituíam a principal ocupação das religiosas. Tanto a Segunda Regra de Santa Clara - que, aprovada pelo papa Urbano IV em 1263, foi mandada observar com adaptaçôes em 1726 no Convento do Desterro pelo arcebispo da Bahia D. Luís Alves de Figueiredo - quanto as Constituições gerais para as freiras da família franciscana estipulavam o exercício no coro para todas as religiosas nos conventos, durante as oito horas canônicas diárias. Aquelas que não soubessem ler deveriam rezar no mesmo coro pais-nossos, ave-marias e outras orações. O ofício deveria ser rezado em cantochão, sem acompanhamento de órgão. ${ }^{57}$ Não obstante as prescrições formais, a prática religiosa de Maria da Soledade continha um fervor que trazia estranhamento às demais religiosas:

Às cinco horas da manhã já estava de pé, preparando-se para ir ao coro, e quando saía sempre era com tal pressa, que era quase de carreira, como que lhe faltava o tempo, e quem assim a via cuidava ir fugindo de alguma coisa, e sem falar às que encontrava, e da mesma sorte entrava pelo coro, e como uma esfaimada, já com os olhos no sacrário, ajoelhava com a sua costumada postura, com as mãos levantadas. ${ }^{58}$

As formas de devoção de Maria da Soledade eram centradas na figura de Cristo, em suas diversas representações. A adoração ao Santíssimo Sacramento foi a mais exacerbada, conforme se apura no seguinte trecho:

E foi muito para notar que em tantos anos, quantos são os sobreditos, que habitou neste Convento, nunca se abrisse o Sacrário, nem de dia, nem de noite, que ela se não achasse presente; e isto, ou fosse para dar a comunhão, ou saísse fora o Senhor por Viático, e ela sempre o ficava acompanhando de joelhos até tornar. ${ }^{59}$

A presença real de Cristo na eucaristia, defendida pela Igreja desde a Baixa Idade Média, foi reafirmada com veemência em meio às controvérsias teológicas com os protestantes, no século XVII. ${ }^{60}$ Não obstante, além do aspecto dogmático que desempenhava para a Igreja e do caráter de preceito constituído para todos os fiéis, tendo em vista a obrigatoriedade da comunhão anual, em torno do Santíssimo Sacramento floresceram práticas devocionais. Tais exercícios permitiam aos devotos um envolvimento sagrado mais intenso com a eucaristia, para além da missa. Assim, multiplicaram-se no período moderno, tanto na Europa quanto na Colônia, as referidas práticas piedosas, como a adoração de quarenta horas do Santíssimo Sacramento, a exposição pública da eucaristia na Semana Santa, as visitas 
etc. ${ }^{61}$ As práticas de piedade de Maria da Soledade estavam inseridas aproximadamente nesse quadro. Deste modo, ficava absorvida por horas a fio na adoração eucarística. Durante a comunhão, a sua face se ruborizava de júbilo. Chegou inclusive a mandar trazer de Portugal um sacrário de prata para a guarda das hóstias, pois o de madeira que havia no Convento não era tão bom. Segundo o Novo Orbe serafico, "costumava dizer que ela era cativa do seu Senhor Sacramentado". ${ }^{62}$ A sua absoluta confiança na proteção do sacramento eucarístico evidenciou-se ainda em outra oportunidade, em comentário que dirigiu a uma irmã no Convento: "diante do Santíssimo Sacramento não temo, porque ali estou capaz de brigar com todo o Inferno". ${ }^{63} \mathrm{O}$ culto à infância de Cristo foi também significativo para Maria da Soledade. Na sua cela, "fazia-lhe todos os anos a sua lapinha com muita perfeição". Além disso, "mandou buscar umas Imagens muito perfeitas para fabricar uma capela do Nascimento para o que dava a sua mesma cela, acomodando-se em uma antiga, se houvesse para isso licença dos Prelados". Não se sabe se esta proposta foi concretizada. Não obstante, há indícios aqui para inserir Maria da Soledade em uma linhagem de mulheres piedosas que, desde a Baixa Idade Média, encontravam na eucaristia o caráter material da humanidade de Cristo, com o qual literalmente alimentavam a sua devoção. ${ }^{64}$

Essa materialidade da devoção a Cristo evidenciava-se também na atenção dedicada por Maria da Soledade aos paramentos do altar. Entre oito ou nove horas, quando se recolhia à cela após as obrigaçôes do coro, até a meia noite, ocupava-se "em fazer rendas e costuras para os Altares e Igrejas (...) e se lhe perguntavam para que cozia tanto, respondia: Estou fazendo rendas para os lenços de meu Esposo". Em outra passagem, fica reforçada a impressão de que a confecção das alfaias litúrgicas assumia um caráter de devoção pessoal de Maria da Soledade a Cristo: "nunca deu ponto que não fosse para Deus, e para o seu santo serviço, de sorte que as suas próprias camisas mandava fazer por qualquer Pessoa, ou bem ou mal cozidas, por se não tirar do seu frequente exercício de cozer para Deus" ${ }^{65}$ Nesse ponto, surge outro paralelo entre a hagiografia de Santa Clara reproduzida por Cornejo e a narrativa do Novo Orbe serafico. O cronista franciscano, ao enfocar a "devoção ardente que teve Santa Clara ao Santíssimo Sacramento do Altar", menciona que estando enferma na cama, dedicava-se a fiar corporais para as igrejas pobres de Assis e das aldeias vizinhas. ${ }^{66}$ Não obstante, se para a santa de Assis a devoção eucarística não tinha uma importância equivalente à valorização do trabalho manual, para Maria da Soledade, o Santíssimo Sacramento figurava no centro da prática devocional. ${ }^{67}$

O exercício da pobreza ocupa um lugar reduzido na narrativa transcrita por Jaboatão. Maria da Soledade atendia às necessidades corporais das pobres, "tirando muitas vezes da boca para dar-lhes". Além disso, provia-lhes alimento para o espírito, pois "as consolava, falando-lhes de Deus; e pela sua boa prática e companhia, lhe rogavam, quando se apartava, que tornasse". Assim, a narrativa faz referências a mulheres pobres, cuja assistência era efetuada pela religiosa sem prejudicar os exercícios do coro. ${ }^{68}$ É evidente aqui certa distância entre a prática da caridade empreendida por Maria da Soledade e o ideal de partilha e identificação com os pobres que moveu Santa Clara ${ }^{69}$ Por vezes, entretanto, a prática do ideal de pobreza aparecia com mais força. Quando os seus parentes lhe enviavam presentes, "na mesma hora dava tudo, sem reservar para si coisa alguma". A narrativa lança mais luz sobre a austeridade colocada em prática pela freira baiana:

Nunca admitiu Serva para a servir em todo o tempo, que viveu neste Convento, e por sua mão varria a sua cela, fazia a cama e todo o mais serviço, que lhe era necessário; e quando lhe diziam porque não admitia, como as mais, a sua Serva, respondia que não; porque enquanto Deus lhe dava saúde bem podia servir-se por si. ${ }^{70}$

A historiografia faz referência à significativa existência no claustro do Desterro de servas, uma categoria de mulheres que não se confundia com as escravas. Uma autora alude à presença de servas particulares e da comunidade. Estas, que tinham status superior às primeiras, eram em geral donzelas brancas pobres ou órfãs que encontravam no Convento uma forma segura de manter um estado honrado. Segundo a mesma autora, o número de servas cresceu de forma expressiva ao longo do século XVIII: em 1704, havia 80 religiosas e nenhuma serva ou escrava. Em 1745, para um total de 102 religiosas, havia 
28 servas da comunidade, 153 particulares e 140 escravas. ${ }^{71}$ De acordo com Soeiro, o número de servas estava inicialmente limitado a 15 mulheres. A condição de liberdade as distinguia das demais escravas. A partir da década de 1720 , ingressaram as primeiras servas mulatas ou negras no Convento. ${ }^{72}$ Assim, parece ter ocorrido um substancial aumento do número de servas no período em que medeia a morte de Maria da Soledade (1719) e a de sua biógrafa, Margarida da Coluna (1743).

Dentro do referido intervalo, em 1726, o arcebispo da Bahia, D. Luís Alves de Figueiredo, sob cuja jurisdição foi instituído o estabelecimento conventual, elaborou estatutos para as religiosas, tendo para isso utilizado e mitigado a Segunda Regra de Santa Clara. Até aquela data, segundo a mesma autora, as clarissas do Convento do Desterro "guardavam os ditames da regra de São Bento, transferida à Bahia pelas religiosas fundadoras, de Évora" ${ }^{73}$ É possível que a atenuação do regime de clausura, efetuada pelo prelado baiano, tenha tido algum efeito sobre o aumento da quantidade de servas ingressantes no Convento.

Segundo o Novo Orbe serafico, Maria da Soledade se destacou ainda pela estrita observância do silêncio, uma cláusula presente tanto na Segunda Regra de Santa Clara quanto nos estatutos conventuais de $1726 .{ }^{74}$ Nas horas em que se impunha o silêncio,

Fazia que o guardassem as que estavam com ela, e de contínuo não falava até o meio dia, porque estava sempre assistindo no coro, e só falava para mandar tocar sino para as missas, dizendo assim: Toquem lá a missa (...) e para dizer as tais palavras saía para fora do coro (sic); porque nele nunca falou, guardando ali perpétuo silêncio, e se lhe perguntavam alguma coisa respondia por acenos, e se era forçoso falar, saía da porta do coro para fora, e aí dava a resposta. ${ }^{75}$

Evitava também murmurações, "nem consentia que em sua presença o fizessem as mais" irmãs de hábito. Não obstante, acabou sendo punida com onze dias de prisão no Convento, onde

Foi incriminada por alguns gênios discordes e mal afetos de que falava em as faltas comuns de pessoas particulares, e de serem pouco observantes de sua Regra, o que sendo assim sempre nela se devia entender zelo da Religião, e não crítica ou mal dizer, como o supuserão. ${ }^{76}$

Assim, de acordo com a biógrafa Margarida da Coluna, a pena de confinamento imposta à sua companheira teria sido tramada por religiosas que toleravam os desvios da Regra, e que se sentiam pouco à vontade com as repreensões públicas insinuadas por Maria da Soledade. Pode-se intuir aqui um conflito entre dois grupos: um constituído pelas duas freiras supracitadas e, muito provavelmente, por outras irmãs de hábito mais zelosas das observâncias da vida no claustro; e outro formado por mulheres que, acostumadas ao viver senhorial, não faziam maiores esforços para abandoná-lo, em detrimento da prática da caridade, do voto de pobreza, da humildade e de outras obrigaçôes próprias do seu estado. Não se pode excluir desse segundo grupo as vocaçôes forçadas, isto é, mulheres encaminhadas à vida conventual por conta dos arranjos familiares. ${ }^{77}$ Pode ser sugestivo indicar que a narrativa da vida de Maria da Soledade pode ter constituído um espelho de perfeição especialmente direcionado às irmãs de hábito pouco observantes, com as quais a freira entrou gravemente em conflito no Convento.

Sem entrar em detalhes a respeito da morte de Maria da Soledade, que reproduz os topoi hagiográficos presentes nas vidas de santos e de outros relatos de exemplar virtude, cabem apenas mais alguns comentários a respeito das relações entre a freira e os seus confessores e diretores espirituais. ${ }^{78} \mathrm{~A}$ religiosa praticava os exercícios de Santo Inácio de Loyola, conforme alude expressamente a crônica. ${ }^{79}$ Entrou certamente em contato com os referidos ensinamentos junto aos jesuítas na capital da Colônia. Em 1717, o padre Domingos Ramos praticou os exercícios espirituais com as religiosas do Convento, por iniciativa do reitor do Colégio da Bahia. ${ }^{80}$ Logo após a profissão solene, efetuada em 1688, Maria da Soledade tomou como confessor o padre Estêvão Gandulfi. Posteriormente, este foi substituído pelo padre Antonio Maria Bonuci. Segundo o historiador da Companhia de Jesus, ambos estavam inscritos entre os padres professos da Província do Brasil, em 1701. ${ }^{81}$ A mudança dos confessores, segundo o Novo Orbe serafico, constituiu mais uma demonstração de humildade da religiosa. Assim, quando Gan- 
dulfi conheceu "o seu relevante espírito, ela o deixou". Do mesmo modo, quando Bonuci disse a outras religiosas que Maria da Soledade era "uma pedra preciosa lavrada e perfeita, fugiu também dele, e nunca mais quis ter confessor certo. Entendiam as religiosas era isto por ocultar a sua virtude, como o fazia em tudo o mais". ${ }^{82}$ Por fim, o vínculo com os religiosos jesuítas ficou uma vez mais evidenciado por ocasião da própria morte, quando mandou chamar o padre mestre de noviços do Colégio da Bahia para a última confissão. Enquanto aguardava a chegada do confessor, fez um ato de contrição que lhe fora ensinado pelo diretor das religiosas, o padre mestre Domingos Ramos, já referido. ${ }^{83}$

Os três relatos compilados por Jaboatão, que tratavam da vida e virtudes de Antônia de Pádua de Góes, de Catharina Paes Landim e da sóror Maria da Soledade, podem ser vistos como narrativas modelares, em um duplo aspecto. Em primeiro lugar, ao fornecer exemplos de comportamento virtuoso para mulheres situadas em diferentes estados, a saber: casadas, viúvas, beatas e freiras. Em segundo lugar, por encontrar inspiração em textos hagiográficos que retratavam santas que passaram pela experiência do matrimônio, da viuvez e do ingresso na Ordem Terceira de São Francisco, como foi o caso de Santa Isabel, e pela vida do claustro, como ocorreu com Santa Clara. No interior de cada relato, os modelos enfatizavam comportamentos adequados a cada um dos estados das mulheres enfocadas: a tolerância face aos maridos, no caso de Antônia de Pádua de Góes e de Catharina Paes Landim; o aprofundamento da vida espiritual propiciado pela viuvez, por meio da prática da caridade e da intermediação de curas miraculosas - de que Antônia constitui exemplo - e uma "conversão" marcada pela busca da penitência por meio da pobreza, do trabalho manual e da renúncia sexual, de que deu testemunho Catharina Paes; a obediência, a humildade, a disciplina e a fervorosa devoção que acompanhavam a vida no claustro, conforme se apurou no testemunho de Maria da Soledade.

\section{Notas}

${ }^{1}$ MARTINS, William de Souza. D. Domingos do Loreto Couto e a construção de modelos de santidade feminina na época colonial. Revista do Mestrado de História. Vassouras, v. 11, p. 193-229, 2009. O Projeto em pauta foi beneficiado com o auxílio APQ1 da FAPERJ.

${ }^{2}$ WILLEKE, Fr. Venâncio, OFM. Frei Antônio de Santa Maria Jaboatão, OFM. Revista de História. São Paulo, v. XLVI, n. 93, jan-mar. 1973, p. 47-67. Este artigo foi republicado com poucas modificações em Franciscanos na História do Brasil. Petrópolis: Vozes, 1977 , p. 88-100.

${ }^{3}$ JABOATÃO, Fr. Antônio de Santa Maria, OFM. Novo Orbe serafico, ou Crônica dos frades menores da Província do Brasil (...). Impressa em Lisboa em 1761, e reimpressa por ordem do Instituto Histórico e Geográfico Brasileiro. Rio de Janeiro: Tip. Brasileira de Máximo Gomes Ribeiro, 1858-1862, 5 v. Nas citaçōes desta obra, deixou-se de lado a divisão em partes, optando-se por considerar em ordem sequencial os volumes. Nesta obra, como nas demais citaçôes de fontes, atualizou-se a grafia utilizada, respeitando-se apenas o uso das maiúsculas. Os títulos originais das publicaçôes foram mantidos.

${ }^{4}$ VAN DER VAT, Fr. Odulfo, OFM. Princípios da Igreja no Brasil. Petrópolis: Vozes, 1952, p. 104-123. MARTINS, William de Souza. Membros do corpo mistico: ordens terceiras no Rio de Janeiro (c. 1700-1822). São Paulo: Edusp, 2009, p. 87.

${ }^{5}$ COUTO, D. Domingos do Loreto, OSB. Desagravos do Brasil e glórias de Pernambuco (1757). Ed. fac-similar da de 1904. Recife: Fundação de Cultura, 1981, p. 511.

${ }^{6}$ JABOATÃO, Fr. Antônio de Santa Maria, Novo Orbe serafico, v. 5, p. 770-779, onde há várias micro-biografias de religiosas do Convento de Santa Clara do Desterro.

${ }^{7}$ Ibid., v. 4, p. 613.

${ }^{8}$ Ibid., v. 5, p. 748.

9 ALGRANTI, Leila Mezan. Honradas e devotas: mulheres da Colônia. Condição feminina nos conventos e recolhimentos do Sudeste do Brasil, 1750-1822. Rio de Janeiro: José Olympio; Brasília: Ed. UnB, 1993, p. 55-81.

${ }^{10}$ ALMEIDA, Suely Creusa Cordeiro de. O sexo devoto: normalização e resistência feminina no Império Português, XVI-XVIII. Recife: Ed. Universitária da UFPE, 2005, p. 289 e 338.

${ }^{11}$ NASCIMENTO, Anna Amélia Vieira. Patriarcado e religião: as enclausuradas clarissas do Convento do Desterro da Bahia, 1677-1890. Bahia: Conselho Estadual de Cultura, 1994. BORGES, Célia Maia. As mensageiras do Senhor: a situação ambígua das beatas na península ibérica - séculos XVI a XVIII. In: ASSIS, Angelo Adriano Faria de e PEREIRA, Mabel Salgado (Orgs.). Religiōes e religiosidades: entre a tradição e a modernidade. São Paulo: Paulinas, 2010, p. 15-27. GONÇALVES, Margareth de Almeida. Império da fé: andarilhas da alma na época barroca. Rio de Janeiro: Rocco, 2005. 
${ }^{12}$ BELLINI, Lígia. "Penas, e glorias, pezar e prazer": espiritualidade e vida monástica feminina em Portugal no Antigo Regime. In: BELLINI, Lígia; SOUZA, Evergton Sales e SAMPAIO, Gabriela dos Reis (Orgs.). Formas de crer: ensaios de história religiosa do mundo luso-afro-brasileiro, séculos XIV-XXI. Salvador: Corrupio, 2006, p. 81-105. BELLINI, Lígia e PACHECO, Moreno Laborda. Experiência e ideais de vida religiosa em mosteiros portugueses clarianos nos séculos XVII e XVIII. Revista de História. São Paulo, v. 160, p. 147-167, 2009.

${ }^{13}$ FERNANDES, Maria de Lurdes Correia. Introdução. In: ANJOS, Fr. Luís dos. Jardim de Portugal (1626). Porto: Campo de Letras, 1999, p. 9-29.

${ }^{14}$ CERTEAU, Michel de. A escrita da História. Rio de Janeiro: Forense Universitária, 1982, p. 272.

${ }^{15}$ JABOATÃO, Fr. Antônio de Santa Maria, op. cit., v. 4, p. 564-572. Exceto quando indicado, as citações de Jaboatão que constam a seguir provém deste trecho.

${ }^{16}$ LEITE, Padre Serafim, SJ. História da Companhia de Jesus no Brasil. Ed. fac-símile da de 1938. Belo Horizonte: Itatiaia, 2006, v. 1, p. 580. Nesta obra, Gaspar de Araújo, pai de Antônia de Pádua de Góes, figura entre os noviços no catálogo dos padres e irmãos da província jesuíta do Brasil no ano de 1600.

${ }^{17}$ Luiz dos Santos VILHENA descreve da forma seguinte a mudança do estabelecimento inicial dos povoadores: "está a vila de Cairu fundada em uma Ilha que terá de duas a três léguas de circunferência situada no canal que divide a grande Ilha do Morro de S. Paulo da terra firme; fundaram ali aquela vila em razão de muitos Gentios que havia no Continente e tudo infestavam". Ver Recopilação de notícias soteropolitanas e brasílicas (1802). Bahia: Imprensa Oficial do Estado, 1921, v. 2 , p. 517.

${ }^{18}$ CAMPOS, João da Silva. Crônica da capitania de Ilhéus. 3. ed. Ilheús: Editus, 2006, p. 104.

${ }^{19}$ A função deste tipo de recolhimento aparece especificada nas atas capitulares da Província no ano de 1653, para uma localidade diversa da vila do Cairu: "Assentou-se em Mesa, que no Pontal de Nazareth ao pé do Monte no sítio mais conveniente se faça um recolhimento de Hospedagem com Oratório ou Igreja de taipas, onde estejam 3 ou 4 religiosos, para se evitarem os discursos inúteis, e agasalharem-se em casa de seculares, e principalmente por acudir ao bem das almas, e administrar os Sacramentos aos Fiéis daquele Povo". WILLEKE, Fr. Venâncio, OFM (int. e notas explicativas). Atas capitulares da Província franciscana de Santo Antônio do Brasil (1649-1893). Revista do IHGB. Rio de Janeiro, v. 286, p. 99, jan.-mar. 1970.

${ }^{20}$ Ibid., p. 77. As atas capitulares do ano de 1681 referem que "o Convento da Bahia dará todos os anos uma arroba de cera ao Convento de Cairu, e o Convento do Cairu não mandará pedir esmola de cera à Bahia”.

${ }^{21}$ JABOATÃO, Fr. Antônio de Santa Maria, op. cit., v. 4, p. 571. Grifos no original. A parte que está em itálico é uma citação feita pelo cronista do relato anônimo em que se baseia.

${ }^{22}$ ARBIOL, Fr. Antonio, OFM. Los terceros hijos de el humano serafin: La venerable y esclarecida Orden Tercera de nuestro serafico Patriarca San Francisco. (...) Quarta impression (...) Zaragaça: por Pedro Carreras, Año 1724, p. 267.

${ }^{23}$ Alguns estudiosos dos relatos hagiográficos de Santa Isabel comentam que o milagre das rosas foi atribuído também à Santa Isabel da Hungria (1207-1231), considerada tia-avó da santa portuguesa, não se sabe pela coincidência dos nomes ou das práticas de caridade. Ver HALLACK, Cecile and ANSON, Peter F. These Made Peace: Studies in the Lives of Beatified and Canonized Members of Third Order of Saint Francis of Assissi. Paterson (New Jersey): St. Anthony Guild Press, 1957, p. 48-52 e 94-98. Segundo estes autores, apenas a partir de 1562 a cena do milagre foi incorporada à vida da santa portuguesa.

${ }^{24}$ ARBIOL, Fr. Antonio, op. cit., p. 260. Nesta passagem, o cronista franciscano refere a intensificação da vida espiritual de Santa Isabel no estado da viuvez: "Vendo-se já a Santa Rainha livre das leis do Mundo, e dos cuidados do Matrimônio, e por isto mais obrigada a servir a Deus no estado de tristeza e solidão de Viúva, com o Hábito de Penitência; procurou primeiramente ajustar sua vida com a Regra da Tercera Ordem de nosso Serafico Patriarca, empregando-se com especial cuidado em esmolas e obras de caridade".

${ }^{25}$ JABOATÃO, Fr. Antônio de Santa Maria, op. cit., v. 4, p. 572.

${ }^{26}$ BELLINI, Lígia e PACHECO, Moreno Laborda, op. cit., p. 159.

${ }^{27}$ GÉLIS, Jacques. O corpo, a Igreja e o sagrado. In: VIGARELLO, Georges (Dir.). Da Renascença às Luzes (História do Corpo, sob a dir. de Alain Corbin, Jean-Jacques Courtine e Georges Vigarello, v. 1). 4. ed. Petrópolis: Vozes, 2010 , p. 77.

${ }^{28}$ A respeito das práticas de caridade no início da Europa Moderna, ver SÁ, Isabel dos Guimarães. Quando o rico se faz pobre: Misericórdias, caridade e poder no império português, 1500-1800. Lisboa: Comissão Nacional para as Comemorações dos Descobrimentos Portugueses, 1997, p. 25-40. Ver também O’MALLEY, John W. Os primeiros jesuitas. São Leopoldo: Ed. Unisinos; Bauru: Edusc, 2004, p. 259-312.

${ }^{29}$ JABOATÃO, Fr. Antônio de Santa Maria, op. cit., v. 4, p. 573-574.

${ }^{30}$ Catálogo dos livros que se hão de ler para a continuação do Dicionário da Língua Portuguesa mandado publicar pela Academia Real das Sciencias de Lisboa. Lisboa: na Tipografia da mesma Academia, 1799, p. 135.

${ }^{31}$ JABOATÃO, Fr. Antônio de Santa Maria, op. cit., v. 4, p. 576.

32 Ibid., p. 576. A respeito da Academia, ver KANTOR, Iris. Esquecidos e Renascidos: historiografia acadêmica luso-americana (1724-1759). São Paulo: Hucitec; Salvador: Centro de Estudos Baianos, 2004, p. 155. 
33 Sobre intermediários, ver VOVELLE, Michel. Ideologias e mentalidades. 2. ed. São Paulo: Brasiliense, 1991, p. $207-224$.

${ }^{34}$ VAINFAS, Ronaldo. Ideologia e escravidão: os letrados e a sociedade escravista no Brasil colonial. Petrópolis: Vozes, 1986, p. 107-115.

${ }^{35}$ Apenas no catálogo da Biblioteca Nacional do Rio de Janeiro, é possível listar as seguintes publicaçōes: CARRILO, Juan. La Historia de Santa Isabel, Infanta de Aragon y Reina de Portugal (...) Caragoça: Juan de Lenaje y Quartanet, 1625; VERA Y ZUNIGA, Juan Antonio. Vida de la gloriosa Santa Isabel Reyna de Portugal (...) Roma: Jacomo Mascardi, 1625; e SOARES, Miguel de Leão. Relacion verdadera, Del aparato y solenidad co que em Roma se celebro la Canonizacion de Santa Isabel Reyna de Portugal (...) Em Madrid: por Diego Flamenco, 1625.

${ }^{36}$ MARQUES, João Francisco. A parenética portuguesa e a Restauração (1640-1668): a revolta e a mentalidade. Porto: INIC, 1989, v. 1, p. 150-152.

${ }^{37}$ JABOATÃO, Fr. Antônio de Santa Maria, op. cit., v. 4, p. 613-615, de onde provêm todas as informações referentes à Catharina Paes Landim, exceto quando indicado em contrário.

38 Ibid., p. 606. Ver também WILLEKE, fr. Venâncio. Atas capitulares da Província franciscana de Santo Antônio do Brasil, op. cit., p. 101.

39 JABOATÃO, Fr. Antônio de Santa Maria, op. cit., v. 4, p. 612.

${ }^{40}$ Idem, Ibid.

${ }^{41}$ Sobre as relações carnais ilícitas e adulterinas praticadas pelos irmãos terceiros fluminenses, ver MARTINS, William de Souza, Membros do corpo místico, cit., p. 334-340.

${ }^{42}$ ARBIOL, Fr. Antonio, op. cit., p. 265.

${ }^{43} \mathrm{O}$ estudo clássico deste tema é o de GRUNDMANN, Herbert. Religious Movements in the Middle Ages: The Historical Links between Heresy, the Mendicant Orders, and Women's Religious Movement in the Twelfth and Thirteenth Century, with the Historical Foundations of German Mysticism. Notre Dame (Indiana): University of Notre Dame Press, 1995, p. 75-137.

${ }^{44}$ Sobre as mudanças ocorridas na espiritualidade no Ocidente Medieval, que abriram espaços para um papel mais ativo dos leigos na vida religiosa, ver VAUCHEZ, André. A espiritualidade na Idade Média ocidental (séculos VIII a XIII). Rio de Janeiro: Jorge Zahar, 1995, p. 90-159.

${ }^{45}$ KING, Margaret L. A mulher do Renascimento. Lisboa: Presença, 1994, p. 113-127.

${ }^{46}$ SILVA, Maria Beatriz Nizza da. Donas e plebeias na sociedade colonial. Lisboa: Estampa, 2002, p. 103-108. Ver também MARIA, Fr. José de Jesus, O. Carm. Tesouro carmelitano manifesto e oferecido aos irmãos e irmãs da Venerável Ordem Terceira da Rainha dos Anjos, Mãe de Deus, Senhora do Carmo, pelo Padre Presentado (...), Comissário da mesma Ordem no Convento do Carmo de Lisboa. Lisboa: na Oficina de Miguel Manescal da Costa, Impressor do Santo Ofício, 1760, p. $233-240$. Com relação à Ordem Terceira de São Francisco, o manual que foi possível consultar é menos preciso em relação à concessão de hábitos exteriores ou descobertos, sublinhando que apenas os prelados da Ordem poderiam legitimamente concedêlos. Ver SOLEDAD, Fr. Domingo de la, OFM. Sol Seraphico que colocado em el cenit del Catholico Cielo, ilustra al Christiano Orbe com los beneficos rayos del Origen, Excelencias, Frutos, Regla, e Indulgencias de la estimada de Dios, apreciada de los Pontifices, y venerada de los Hombres, la siempre Venerable Orden Tercera de Penitencia de N. S. P. S. Francisco (...). s. e, s/d [2. ed. Cádiz: Jeronimo de Peralta, 1728], p. 297-309.

${ }^{47}$ RUBIAL GARCIA, Antonio. Profetisas y solitários. Espacios y mensajes de uma religión dirigida por ermitaños y beatas laicos em las ciudades de Nueva España. Mexico: UNAM: FCE, 2006, p. 31.

${ }^{48}$ MATA, Sergio da. Para uma história das formas de ascetismo leigo em Minas colonial: o caso dos ermitães. In: ASSIS, Angelo Adriano Faria de e PEREIRA, Mabel Salgado, op. cit., p. 29-44.

${ }^{49}$ A respeito dos ermitães na Nova Espanha, ver RUBIAL GARCIA, Antonio. La santidad controvertida. Hagiografia y conciencia criolla alredor de los venerables no canonizados de Nueva España. México: UNAM: FCE, 1999, p. 89-128.

${ }^{50}$ JABOATÃO, Fr. Antônio de Santa Maria, op. cit., v. 5, p. 747-770.

${ }^{51}$ Ibid., v. 5, p. 642-664. Nesta passagem, o cronista franciscano informa que a Madre Margarida da Coluna que redigiu o relato foi a segunda com o referido nome a viver no Convento. Entre as fundadoras do Desterro que vieram de Évora em 1677, estava uma religiosa homônima, que foi eleita como primeira abadessa conventual, entre 1677 e 1686 . Neste último ano, o grupo de freiras eborense retornou ao Reino. Ainda em 1686, entrou no Convento como noviça Margarida da Costa Jardim, que adotou o nome religioso de Margarida da Coluna, talvez em homenagem à fundadora e primeira abadessa. Esta segunda Margarida da Coluna, autora do manuscrito compilado por Jaboatão, exerceu também a dignidade abacial, entre 1732 e 1735, falecendo em 1743, com a idade de 81 anos. Ver NASCIMENTO, Anna Amélia Vieira, op. cit., p. 451.

52 NASCIMENTO, Anna Amélia Vieira, op. cit., p. 111-114 e 307. Ver também SOEIRO, Susan A. A Baroque Nunnery: The Economic and Social Role of a Colonial Convent Santa Clara do Desterro, Salvador, Bahia, 1677-1800. New York University, Ph. D. Thesis, 1974, p. 67-84. SOEIRO, Susan A. The Feminine Orders in Colonial Bahia, Brazil: Economic, Social, and Demographic Implications, 1677-1800. In: LAVRIN, Asunción (Ed.). Latin American Women: Historical Per- 
spectives. Westport (Connecticut): Greenwood Press, 1978, p. 173-197. Para as relações entre a reclusão conventual e o mercado matrimonial no sul da Europa no início do período moderno, ver LAVEN, Mary. Virgens de Veneza: vidas enclausuradas e quebra de votos no convento renascentista. Rio de Janeiro: Imago, 2003, p. 51-65. As mencionadas autoras apontam que os dotes atribuídos às mulheres que seguiam a vida conventual constituíam uma pequena fração do valor daqueles concedidos às que pretendiam o matrimônio.

53 JABOATÃO, Fr. Antônio de Santa Maria, op. cit., v. 5, p. 749. SOEIRO analisou rapidamente a biografia de Maria da Soledade, baseando-se também no Novo Orbe serafico. Ver A Baroque Nunnery, cit., p. 62-63.

${ }^{54}$ BARTOLI, Marco. Clara de Assis. Petrópolis: Vozes, 1998, p. 27-50.

55 CORNEJO, Fr. Damian, OFM. Chronica seraphica dedicada a la excelentissima Señora Duquesa de Aveyro y Maqueda (...). Segunda parte. Año 1727. Madrid: Em la Imprenta de la Viuda de Juan Garcia Infançon, p. 3-6 (a 1a ed. é de 1682). ${ }^{56}$ JABOATÃO, Fr. Antônio de Santa Maria, op. cit., v. 5, p. 749.

${ }^{57}$ Constituciones generales para todas las monjas y religiosas sujetas a la obediência de la orden de N. S. P. S. Francisco em toda esta família cismontana (...) Con Licencia. Em Madrid, En la Imprenta Real. Año de 1642, p. 22 e 60-66. Ver também NASCIMENTO, Anna Amélia Vieira, op. cit., P. 89-100.

${ }^{58}$ JABOATÃO, Fr. Antônio de Santa Maria, op. cit., v. 5, p. 752.

${ }^{59}$ Ibid., p. 757.

${ }^{60}$ PO-CHIA HSIA, R. The World of Catholic Renewal, 1540-1770. Second Ed. Cambridge: Cambridge University Press, 2005 , p. 15.

${ }^{61}$ CHAHON, Sergio. Os convidados para a ceia do Senhor. As missas e a vivência leiga do catolicismo na cidade do Rio de Janeiro e arredores (1750-1820). São Paulo: Edusp, 2008, p. 335-355. LEBRUN, François. As reformas: devoções comunitárias e piedade social. In: ARIÈS, P. e CHARTIER, R. Da Renascença ao Século das Luzes (História da Vida Privada sob a dir. de ARIÈS, P. e DUBY, G., v. 3). São Paulo: Cia. das Letras, 1995, p. 73-83.

${ }^{62}$ JABOATÃO, Fr. Antônio de Santa Maria, op. cit., v. 5, p. 761.

${ }^{63}$ Ibid., p. 765.

${ }^{64}$ BYNUM, Caroline Walker. Women Mystics and Eucharistic Devotion in the Thirteenth Century. In: Fragmentation and Redemption. Essays on Gender and Human Body in Medieval Religion. New York: Zone Books, 1992, p. 119-150.

${ }^{65}$ JABOATÃO, Fr. Antônio de Santa Maria, op. cit., v. 5, p. 753.

${ }^{66}$ CORNEJO, Fr. Damian, op. cit., p. 49. Ver também um trecho similar contido em um influente manual devocional: "entre outras devoções que a santa virgem tinha foi muito admirável a do santíssimo Sacramento. Comungava muito frequentemente; fiava com suas mãos, ainda estando doente de cama, lenços delicadíssimos para corporais e serviço do Altar, e repartia-os por todas as Igrejas da cidade de Assis". RIBADENEIRA, Pe. Pedro de, SJ. Flos Sanctorum o libro de las vidas de los santos (...) Primera parte. Año 1675. Con Privilegio. En Madrid: Em la Imprenta Real, p. 439.

${ }^{67}$ BARTOLI, Marco, op. cit., p. 75-79.

${ }^{68}$ JABOATÃO, Fr. Antônio de Santa Maria, op. cit., v. 5, p. 755.

${ }^{69}$ BARTOLI, Marco, op. cit., p. 55.

${ }^{70}$ JABOATÃO, Fr. Antônio de Santa Maria, op. cit., v. 5, p. 754.

${ }^{71}$ NASCIMENTO, Anna Amélia Vieira, op. cit., p. 115-116 e 129.

72 SOEIRO, Susan A. A Baroque Nunnery, cit., p. 53-55.

${ }^{73}$ NASCIMENTO, Anna Amélia Vieira, op. cit., p. 89-99. A citação está na primeira página.

${ }^{74}$ Para a Regra, ver Constituciones generales, cit., p. 24-25. Quanto aos estatutos, ver NASCIMENTO, Anna Amélia Vieira, op. cit., p. 93. Segundo BARTOLI, Marco, op. cit., p. 104, "Clara nunca acolheu a proibição de falar. Fez do diálogo espiritual e da pregação pontos centrais da vida de sua comunidade”, o que afasta a vivência religiosa de Maria da Soledade daquela desenvolvida pela fundadora da Ordem.

75 JABOATÃO, Fr. Antônio de Santa Maria, op. cit., v. 5, p. 755.

${ }^{76}$ Ibid., p. 756.

${ }^{77}$ KING, Margaret, op. cit., p. 91-103, acerca do quadro europeu.

${ }^{78}$ BARTOLI, Marco, op. cit., p. 116, para a definição de topos hagiográfico.

79 JABOATÃO, Fr. Antônio de Santa Maria, op. cit., v. 5, p. 760.

${ }^{80}$ LEITE, Pe. Serafim, SJ. História da Companhia de Jesus no Brasil. Rio de Janeiro: INL; Lisboa: Livraria Portugália, 1945, t. V, p. 156.

${ }^{81}$ Ibid., p. 581. Na fonte em questão, os nomes aparecem latinizados: “Stephanus Gandolfi” e Antonius Ma Bonucius”. 
${ }^{82}$ JABOATÃO, Fr. Antônio de Santa Maria, op. cit., v. 5, p. 761.

${ }^{83}$ Ibid., p. 768-769.

\section{Fontes impressas}

ARBIOL, Fr. Antonio, OFM. Los terceros hijos de el humano serafin: La venerable y esclarecida Orden Tercera de nuestro serafico Patriarca San Francisco. (...) Quarta impression (...) Zaragaça: por Pedro Carreras, Año 1724.

Catálogo dos livros que se hão de ler para a continuação do Dicionário da Lingua Portuguesa mandado publicar pela Academia Real das Sciencias de Lisboa. Lisboa: na Tipografia da mesma Academia, 1799.

Constituciones generales para todas las monjas y religiosas sujetas a la obediência de la orden de N. S. P. S. Francisco em toda esta família cismontana (...) Con Licencia. Em Madrid, En la Imprenta Real. Año de 1642.

CORNEJO, Fr. Damian, OFM. Chronica seraphica dedicada a la excelentissima Señora Duquesa de Aveyro y Maqueda (...). Segunda parte. Año 1727. Madrid: Em la Imprenta de la Viuda de Juan Garcia Infançon, p. 3-6 (a $1^{\text {a }}$ ed. é de 1682).

COUTO, D. Domingos do Loreto, OSB. Desagravos do Brasil e glórias de Pernambuco (1757). Ed. fac-similar da de 1904. Recife: Fundação de Cultura, 1981.

JABOATÃO, Fr. Antônio de Santa Maria, OFM. Novo Orbe serafico ou Crônica dos frades menores da Provincia do Brasil (...). Impressa em Lisboa em 1761, e reimpressa por ordem do Instituto Histórico e Geográfico Brasileiro. Rio de Janeiro: Tip. Brasileira de Máximo Gomes Ribeiro, 1858-1862, 5 v.

MARIA, Fr. José de Jesus, O. Carm. Tesouro carmelitano manifesto e oferecido aos irmãos e irmãs da Venerável Ordem Terceira da Rainha dos Anjos, Mãe de Deus, Senhora do Carmo, pelo Padre Presentado (...), Comissário da mesma Ordem no Convento do Carmo de Lisboa. Lisboa: na Oficina de Miguel Manescal da Costa, Impressor do Santo Ofício, 1760.

RIBADENEIRA, Pe. Pedro de, SJ. Flos Sanctorum o libro de las vidas de los santos (...) Primera parte. Año 1675. Con Privilegio. En Madrid: Em la Imprenta Real.

SOLEDAD, Fr. Domingo de la, OFM. Sol Seraphico que colocado em el cenit del Catholico Cielo, ilustra al Christiano Orbe com los beneficos rayos del Origen, Excelencias, Frutos, Regla, e Indulgencias de la estimada de Dios, apreciada de los Pontifices, y venerada de los Hombres, la siempre Venerable Orden Tercera de Penitencia de N. S. P. S. Francisco (...). s. e, s/d [2. ed. Cádiz: Jeronimo de Peralta, 1728].

VILHENA, Luiz dos Santos. Recopilação de notícias soteropolitanas e brasílicas (1802). Bahia: Imprensa Oficial do Estado, 1921, 2 v.

WILLEKE, Fr. Venâncio, OFM (int. e notas explicativas). Atas capitulares da Província franciscana de Santo Antônio do Brasil (1649-1893). Revista do IHGB. Rio de Janeiro, v. 286, p. 92-222, jan.-mar. 1970.

\section{Referências bibliográficas}

ALGRANTI, Leila Mezan. Honradas e devotas: mulheres da Colônia. Condição feminina nos conventos e recolhimentos do Sudeste do Brasil, 1750-1822. Rio de Janeiro: José Olympio; Brasília: Ed. UnB, 1993.

ALMEIDA, Suely Creusa Cordeiro de. O sexo devoto: normalização e resistência feminina no Império Português, XVI-XVIII. Recife: Ed. Universitária da UFPE, 2005.

BARTOLI, Marco. Clara de Assis. Petrópolis: Vozes, 1998.

BELLINI, Lígia. "Penas, e glorias, pezar e prazer”: espiritualidade e vida monástica feminina em Portugal no Antigo Regime. In: BELLINI, Lígia; SOUZA, Evergton Sales e SAMPAIO, Gabriela dos Reis (Orgs.). Formas de crer: ensaios de história religiosa do mundo luso-afro-brasileiro, séculos XIV-XXI. Salvador: Corrupio, 2006, p. 81-105.

BELLINI, Lígia e PACHECO, Moreno Laborda. Experiência e ideais de vida religiosa em mosteiros portugueses clarianos nos séculos XVII e XVIII. Revista de História. São Paulo, v. 160, p. 147-167, 2009.

BORGES, Célia Maia. As mensageiras do Senhor: a situação ambígua das beatas na península ibérica - séculos XVI a XVIII. In: ASSIS, Angelo Adriano Faria de e PEREIRA, Mabel Salgado (Orgs.). Religiōes e religiosidades: entre a tradição e a modernidade. São Paulo: Paulinas, 2010, p. 15-27. 
BYNUM, Caroline Walker. Women Mystics and Eucharistic Devotion in the Thirteenth Century. In: Fragmentation and Redemption. Essays on Gender and Human Body in Medieval Religion. New York: Zone Books, 1992, p. 119-150.

CAMPOS, João da Silva. Crônica da capitania de Ilhéus. 3. ed. Ilheús: Editus, 2006.

CERTEAU, Michel de. A escrita da História. Rio de Janeiro: Forense Universitária, 1982.

CHAHON, Sergio. Os convidados para a ceia do Senhor. As missas e a vivência leiga do catolicismo na cidade do Rio de Janeiro e arredores (1750-1820). São Paulo: Edusp, 2008.

FERNANDES, Maria de Lurdes Correia. Introdução. In: ANJOS, Fr. Luís dos. Jardim de Portugal (1626). Porto: Campo de Letras, 1999, p. 9-29.

GÉLIS, Jacques. O corpo, a Igreja e o sagrado. In: VIGARELLO, Georges (Dir.). Da Renascença às Luzes (História do Corpo, sob a dir. de Alain Corbin, Jean-Jacques Courtine e Georges Vigarello, v. 1). 4. ed. Petrópolis: Vozes, 2010, p. 19-130.

GONÇALVES, Margareth de Almeida. Império da fé: andarilhas da alma na época barroca. Rio de Janeiro: Rocco, 2005.

GRUNDMANN, Herbert. Religious Movements in the Middle Ages: The Historical Links between Heresy, the Mendicant Orders, and Women's Religious Movement in the Twelfth and Thirteenth Century, with the Historical Foundations of German Mysticism. Notre Dame (Indiana): University of Notre Dame Press, 1995.

HALLACK, Cecile and ANSON, Peter F. These Made Peace: Studies in the Lives of Beatified and Canonized Members of Third Order of Saint Francis of Assissi. Paterson (New Jersey): St. Anthony Guild Press, 1957.

KANTOR, Iris. Esquecidos e Renascidos: historiografia acadêmica luso-americana (1724-1759). São Paulo: Hucitec; Salvador: Centro de Estudos Baianos, 2004.

KING, Margaret L. A mulher do Renascimento. Lisboa: Presença, 1994.

LEBRUN, François. As reformas: devoções comunitárias e piedade social. In: ARIÈS, P. e CHARTIER, R. Da Renascença ao Século das Luzes (História da Vida Privada sob a dir. de ARIĖS, P. e DUBY, G., v. 3). São Paulo: Cia. das Letras, 1995.

LEITE, Padre Serafim, SJ. História da Companhia de Jesus no Brasil. Ed. fac-símile da de 1938. Belo Horizonte: Itatiaia, 2006, $10 \mathrm{v}$.

MARTINS, William de Souza. D. Domingos do Loreto Couto e a construção de modelos de santidade feminina na época colonial. Revista do Mestrado de História. Vassouras, v. 11, p. 193-229, 2009.

. Membros do corpo mistico: ordens terceiras no Rio de Janeiro (c. 1700-1822). São Paulo: Edusp, 2009.

MARQUES, João Francisco. A parenética portuguesa e a Restauração (1640-1668): a revolta e a mentalidade. Porto: INIC, 1989, $2 \mathrm{v}$.

MATA, Sergio da. Para uma história das formas de ascetismo leigo em Minas colonial: o caso dos ermitães. In: ASSIS, Angelo Adriano Faria de e PEREIRA, Mabel Salgado (Orgs.). Religiōes e religiosidades: entre a tradição e a modernidade. São Paulo: Paulinas, 2010, p. 29-44.

NASCIMENTO, Anna Amélia Vieira. Patriarcado e religiāo: as enclausuradas clarissas do Convento do Desterro da Bahia, 1677-1890. Bahia: Conselho Estadual de Cultura, 1994.

O’MALLEY, John W. Os primeiros jesuitas. São Leopoldo: Ed. Unisinos; Bauru: Edusc, 2004.

PO-CHIA HSIA, R. The World of Catholic Renewal, 1540-1770. Second Ed. Cambridge: Cambridge University Press, 2005.

RUBIAL GARCIA, Antonio. Profetisas y solitários. Espacios y mensajes de uma religión dirigida por ermitaños y beatas laicos em las ciudades de Nueva España. Mexico: UNAM: FCE, 2006.

La santidad controvertida. Hagiografia y conciencia criolla alredor de los venerables no canonizados de Nueva España. México: UNAM: FCE, 1999

SÁ, Isabel dos Guimarães. Quando o rico se faz pobre: misericórdias, caridade e poder no império português, 15001800. Lisboa: Comissão Nacional para as Comemorações dos Descobrimentos Portugueses, 1997.

SOEIRO, Susan A. The Feminine Orders in Colonial Bahia, Brazil: Economic, Social, and Demographic Implications, 1677-1800. In: LAVRIN, Asunción (Ed.). Latin American Women: Historical Perspectives. Westport (Connecticut): Greenwood Press, 1978, p. 173-197. 
. A Baroque Nunnery: The Economic and Social Role of a Colonial Convent Santa Clara do Desterro, Salvador, Bahia, 1677-1800. New York University, Ph. D. Thesis, 1974.

SILVA, Maria Beatriz Nizza da. Donas e plebeias na sociedade colonial. Lisboa: Estampa, 2002.

VAINFAS, Ronaldo. Ideologia e escravidão: os letrados e a sociedade escravista no Brasil colonial. Petrópolis: Vozes, 1986.

VAN DER VAT, Fr. Odulfo, OFM. Princípios da Igreja no Brasil. Petrópolis: Vozes, 1952.

VAUCHEZ, André. A espiritualidade na Idade Média ocidental (séculos VIII a XIII). Rio de Janeiro: Jorge Zahar, 1995.

VOVELLE, Michel. Ideologias e mentalidades. 2. ed. São Paulo: Brasiliense, 1991.

WILLEKE, Fr. Venâncio, OFM. Frei Antônio de Santa Maria Jaboatão, OFM. Revista de História. São Paulo, v. XLVI, n. 93, jan-mar. 1973, p. 47-67.

\section{RESUMO}

$O$ artigo pretende analisar a construção de modelos de santidade feminina no Novo Orbe serafico brasilico, a obra mais conhecida do frade franciscano Antônio de Santa Maria Jaboatão (1695-1779). No livro em pauta, são analisados três relatos de vida: o da viúva Antônia de Pádua de Góes (†1643), o da beata Catharina Paes Landim (†1748) e o da freira Maria da Soledade (1668-1719). A hipótese sustentada é a de que as diferentes narrativas serviriam como modelos de virtude para as mulheres coloniais pertencentes aos estados de casada, viuva, beata e religiosa. Por outro lado, os relatos transcritos e adaptados por Jaboatão provavelmente sofreram influências de modelos narrativos hagiográficos, particularmente aqueles inspirados nas vidas de Santa Isabel, rainha de Portugal, e Santa Clara de Assis.

Palavras-chave: santidade feminina, práticas devocionais, catolicismo colonial, Bahia, século XVIII.

\section{ABSTRACT}

The article intends to discuss the construction of models of womanly holiness in Novo Orbe serafico brasilico, the bestknown work of the Franciscan friar Antônio de Santa Maria Jaboatão (1695-1779). In the book under discussion, are reviewed three reports of life: widow Antonia de Padua de Goes (†1643), beata Catharina Paes Landim ( $†$ 1748) and nun Maria da Soledade (1668-1719). The hypothesis is that the different narratives serve as models of virtue for colonial women belonging to the states of married, widowed, beata and nun. On the other hand, reports transcribed and adapted by Jaboatão probably suffered influences of hagiographic narrative models, particularly those inspired by the lives of Santa Isabel (1271-1336), Queen of Portugal, and St. Clara of Assisi (1194-1253).

Keywords: womanly holiness, devotional practices, colonial Catholicism, Bahia, XVIII' century. 